\title{
A Survey of the Experiences of African Librarians in American Academic Libraries
}

\section{Abiodun I. Ibraheem and Christopher Devine}

\begin{abstract}
A national research study was undertaken to identify and clarify issues related to the employment in academic settings of African librarians who have relocated to the United States. It examined, by means of a survey, employment issues concerned with education, credentialing, language skills and cultural bias from the perspective of those librarians and concluded with a recommendation regarding the manner in which their skills might be utilized for the benefit of their homelands.
\end{abstract}

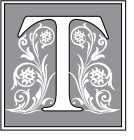

he large-scale emigration of African people that has taken place in the last 50 years has been one of the defining aspects of Africa's post-colonial history. Over that period of time, millions of Africans have left their native countries due to a host of precipitating factors that, at various times and places, have included armed conflict, economic and agricultural disruption, environmental degradation, social turmoil, and political upheaval. ${ }^{1}$ The successive waves of this diaspora have contained the educated and technically skilled workers whose loss formed the "brain drain" that has deprived the continent of many of its most talented and promising young minds. Among them have been an unknown number of librarians who have left Africa and gone on to establish permanent residency in the United States of America and Europe. Heretofore, no collective portrait of these librarians has existed, and the research conducted for this study seeks to fill some of the gaps in knowledge for one particular subset of this group: those who have gone on (or at least sought) to work as academic librarians in the United States. In so doing, it has attempted to ascertain the reasons behind these individuals' departure, the nature of their professional training both in Africa and abroad and the experiences that they have encountered in establishing their careers.

\section{Research Questions}

The study sought to answer several basic questions: what are the salient characteristics of African librarians who have

Abiodun I. Ibraheem is Head, Cataloging E Government Documents Librarian, and Christopher Devine is Interim Library Director at Robert Morris University, Moon Township, Pennsylvania; e-mail: ibraheem@ rmu.edu, devinec@rmu.edu. The authors wish to thank Dr. Jacqueline C. Klentzin, Professor of Learning Resources and Outreach and Information Literacy Librarian at Robert Morris University, for her help in refining the study's survey instrument. Very special thanks are due as well to Dr. Mary A. Hansen, Associate Professor of Education at Robert Morris University, for the invaluable assistance that she provided to this project. (C2013 Abiodun I. Ibraheem and Christopher Devine, Attribution-NonCommercial (http:// creativecommons.org/licenses/by-nc/3.0/) CC BY-NC 
immigrated to the United States of America and are now employed in academic libraries? Why did these individuals emigrate and what are their educational backgrounds? What are their perceptions regarding the experiences that they have had seeking employment and working in American academic libraries? And, finally, what are their opinions regarding a range of issues that affect not only Africans but many other immigrant librarians who have relocated to the United States?

\section{Literature Review}

The term "diaspora" - a transliterated

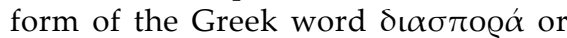
"dispersion" - first entered the English language at the end of the 19th century. ${ }^{2}$ Since then, it has most frequently been employed in connection with the large-scale, forced movement of three groups of people: Jews at various times throughout the millennia, Armenians in the years following the First World War, and Africans during the period of the Atlantic slave trade (1451-1870) as well as the (relatively) voluntary migrations of the postcolonial period. ${ }^{3}$ Although some very thorough works have been written in recent years on the history of the African diaspora, the authors of those books (such as Conniff, Segal, Manning, and Gomez) have all focused on the broad historical and cultural implications of the movement rather than its impact on specific professions such as librarianship. ${ }^{4}$

The so-called "brain drain" - the flow of highly educated or technically skilled workers from developing to developed countries - is one of the most vexing consequences of the contemporary African diaspora and one that has been the subject of an immense amount of research since it was first recognized in the mid-1960s. The definition of "skilled workers" is variable in these studies, but it is usually considered to include, at the very least: "highlevel and general managers; scientists, engineers and those with professional technical skills; professionals in education, health and welfare; professionals in administration; and professionals in literature, arts and sport." 5

There can be no doubt that the emigration of educated personnel in recent decades has had a devastating impact on African universities. Those losses were precipitated and then exacerbated by the structural adjustment policies that were imposed on many African nations by the World Bank and International Monetary Fund as a condition for lending in the 1980s. ${ }^{6}$ As a consequence of those austerity measures, budgetary allocations for tertiary education were drastically reduced across the continent at the same time that enrollments were rising rapidly due to the success of elementary and secondary school programming in the 1960s and 1970s. ${ }^{7}$ The result was terrible overcrowding in many universities, a disastrous erosion of faculty salaries, and widespread deterioration of the physical and informational infrastructure throughout Africa. ${ }^{8}$ By the mid-1990s, the World Bank estimated that 23,000 academic staff members were leaving Africa annually, and the outflow has continued to this day. ${ }^{9}$ What is not clear, however, is the degree to which these personnel losses have had an effect on African university libraries. In fact, when Diana Rosenberg surveyed 18 academic libraries in 11 African countries in 1995, she came to the conclusion that: "For most libraries numbers of staff and numbers of adequately trained staff are at acceptable levels...this makes a big difference from ten years ago, when the number of professionally trained librarians was too few and lack of training was seen as a key problem area."10 This opinion was echoed in a 2000 Carnegie Corporation conference report titled "Revitalizing African Libraries: The Challenge of a Quiet Crisis," which stated that: "Although there is no lack of professionally trained librarians in university libraries, conference participants voiced concern over a scarcity of knowledge and skills in such areas as financial management, income generation and advocacy, as well as ICT [information and communication technology]."11 
On the other hand, some African librarians have pointedly observed that the brain drain has indeed affected African academic libraries in at least some areas of the continent. In her 2010 survey of 13 library managers from Botswana, Lesotho, Namibia, South Africa, and Swaziland, Matseliso M. Moshoeshoe-Chadzingwa noted that: "Remuneration, deciding salaries, wages and disparities thereto was the most sensitive even problematic area that affects staff individually and collectively, including library managers. It was apparently the strongest cause of staff movements, brain drain from the sub-region and of subsequently low morale of library staff..." ${ }^{12}$ Moshoeshoe-Chadzingwa's findings resemble an observation made by Patrick Ngulube who ten years earlier lamented an alarming loss of trained staff from African archives: "However, the problems of the brain drain and a high staff turnover are not peculiar to Zimbabwe...the problem of staff retention is still prevalent in East and Southern Africa...a great deal of manpower has been trained in the subregion over the years but, regrettably, this manpower has by and large been lost."13

For librarians who have emigrated from Africa to the United States, the acceptability of their foreign educational credentials for work is often a serious concern. Since the year 2000, the policy of the American Library Association with regard to foreign degrees in librarianship has been that, "the master's degree from a program accredited by the American Library Association (or from a master's level program in library and information studies accredited or recognized by the appropriate national body of another country) is the appropriate professional degree for librarians." 14 The policy is, however, nonbinding and, as Michael Dowling has observed: "Libraries in the USA have been slow to review and modify their hiring criteria. Most still require a degree from an ALA-accredited school only." 15 Moreover, factors beyond the control of library administrators such as universitywide and other broad institutional policies, which restrict the employment of candidates educated abroad, can pose additional barriers to the hiring of immigrant librarians. And finally, as Amber T. Burtis and her colleagues have pointed out, when administrators are willing to consider the employment of candidates with foreign credentials, questions and doubt may still exist regarding the equivalence of American and African degrees. ${ }^{16}$ In light of this reality, some immigrant librarians may feel that it is necessary to proactively have their educational backgrounds evaluated by fee-based credential evaluation services or even undertake additional educational studies for American versions of degrees that they already possess.

To date, immigrant librarians in American libraries have been a completely unstudied population. There is a large body of literature that has focused on various aspects affecting minority librarians, but it has never distinguished between members of minorities who were born in or moved to the United States as children and those who immigrated after the age of majority. The authors strongly believe that the linguistic, cultural, and educational issues faced by many adult immigrant librarians (and this is definitely true of Africans) demand special analysis on their own terms. It is in the desire to establish a baseline for future longitudinal and cross-ethnic studies that the origin of the present research lies.

\section{Methodology}

This project attempted to develop, by means of an anonymous survey, a picture of a professional population group that had been completely unstudied. For the purposes of this inquiry, an "African librarian" was defined as a person born in Africa, who emigrated after the age of eighteen and, at the time of the survey, was a resident of the United States of America. In addition, he or she would possess educational credentials that qualified him or her to work professionally as 
a librarian in the United States of America or Africa and was either working or seeking employment as an academic librarian. The questions asked were intended to measure a full range of professional experiences from the respondents' reasons for emigration to their educational training, to their subsequent careers as academic librarians in the United States and their perceptions of cultural barriers that might exist for immigrant librarians in American academic libraries.

Although the authors had originally intended to develop the study's core list of subjects by targeting the members of the Africana Librarians Council and the African Studies Association and augmenting that set by culling additional names from the American Library Directory, that plan was eventually determined to be unacceptably scattershot and was subsequently abandoned. The use of lists of graduates of African library schools and members of national library associations was then considered but ultimately rejected primarily because the authors believed that it posed too much potential for inappropriately overweighting some subgroups and underweighting others in what was almost certainly going to be a small survey sample. Moreover, in subsequent research, the authors were unable to determine that such lists and registers existed on a scale that reflected the intended scope of the project, that they could have provided accurate contact information for the targeted subjects of the survey, or that it would have even been possible to actually obtain those resources from Africa.

In the end, the survey was composed and conducted with online survey software and distributed by means of an invitation letter that was sent to 24 listservs focusing on areas of interest to libraries and librarians. ${ }^{17}$ This mode of dissemination and collection was selected because it theoretically provided equal opportunity for participation to all persons in the survey population as well as offering, in the authors' opinion, the best means at that time of eliciting a sufficient number of responses from a truly representative sample of African librarians of all nationalities: from the employed to those seeking work; from the professionally prominent to the completely obscure.

Nevertheless, it must be acknowledged that, since the actual number of individuals who made up the survey universe was unknown, the response rate of the survey cannot be determined. Consequently, the degree to which the profile derived from this study accurately represents the aggregate of African librarians working in American academic libraries - beyond the subset of those who have access to and participate in listservs - is also unknown.

\section{Profile of Respondents}

A total of 51 responses was received. Of these, $33(64.7 \%)$ were from individuals who reported a profile that was compatible with the survey's working definition of "African librarian." Of the 13 librarians who chose to respond to an optional question regarding their nationality, three were originally from Cameroon, three from Sudan, two from Nigeria, and one each from Ethiopia, Ghana, Kenya, Liberia, and Senegal.

\section{Background Information}

The survey invitation elicited 51 responses of which $33(64.7 \%)$ met the study's definition of an African librarian who was working as or searching for a position as a librarian in an American academic library (see table 1). As was noted above, fewer than half of the respondents chose to answer an optional question regarding their nationality; but, of those who did (with the possible exception of three Sudanese librarians), all were Sub-Saharan in origin. The eight nations represented by these respondents include four of the top five countries of origination for all African immigrants to the United States (Nigeria, Ghana, Ethiopia, and Kenya) with, ironically, only Egypt-a country with a long and rich tradition of libraries and librarianship-missing from the list. $^{18}$ 
The participants' motivations for emigration reflected a full and relatively evenly distributed range of "push" and "pull factors," although positive incentives for relocation (such as "Educational reasons," "Economic opportunity," and "Marriage or reunification with family") clearly predominated.

\section{African Educational and Work Experience}

With regard to educational and work experiences in Africa, 88.4 percent of the respondents reported that they had received a university degree prior to their emigration and 65.3 percent possessed either master's or doctoral degrees (see table 2). Fully 12 of the 14 master's degrees were in librarianship. Over 60 percent of the participants reported having practiced librarianship in their homelands; the vast majority of them $(83.3 \%)$ had experienced an academic setting. Of those who had professional African credentials in librarianship, somewhat less than half $(41.6 \%)$ had their certificates evaluated by an independent agency to determine their degree of equivalence with American professional requirements.

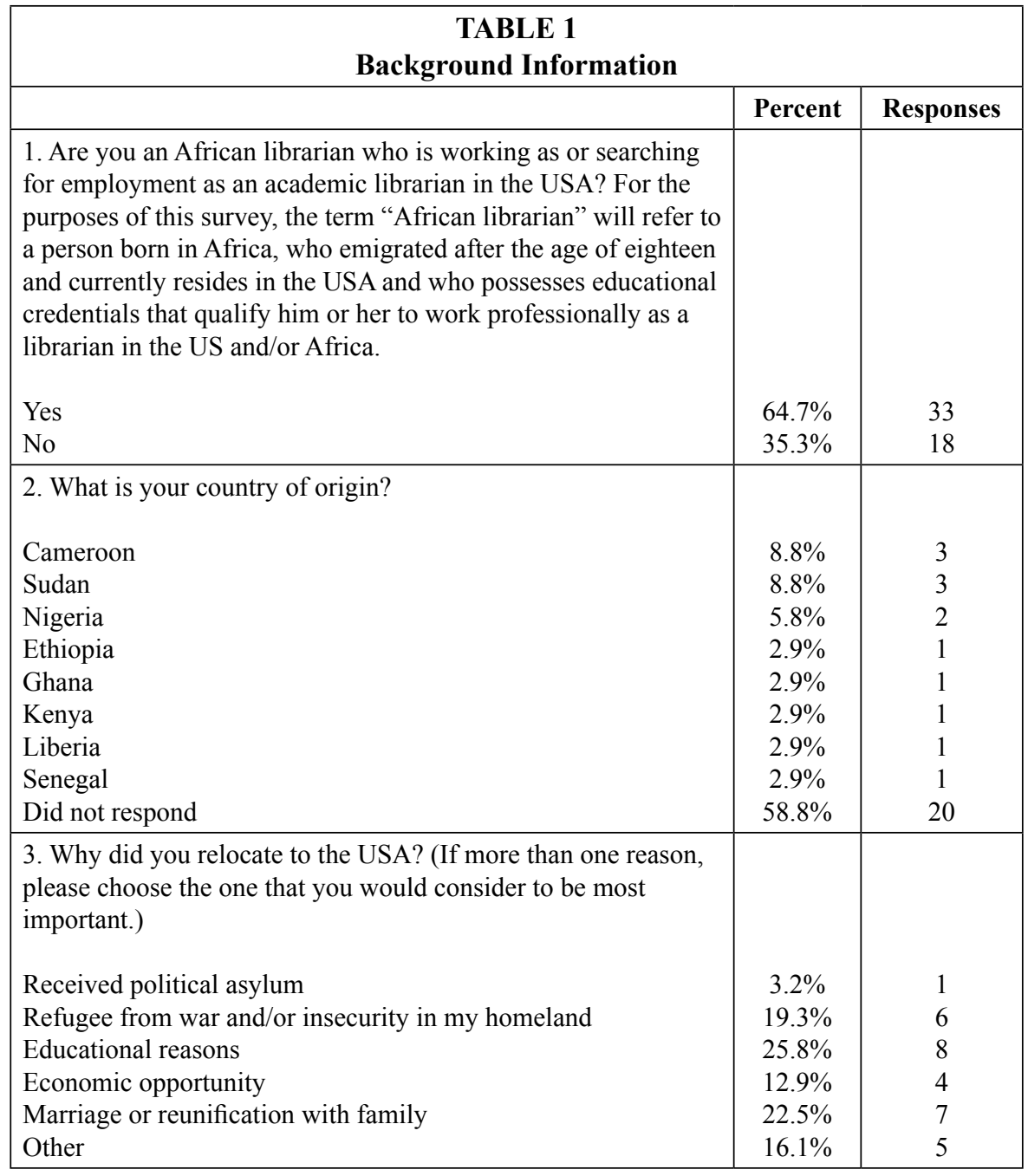


It is noteworthy that inconsistencies were observed between the answers in two pairs of related questions. For instance, in response to Question 5 (“Were any of these degrees in librarianship? [If more than one, please choose the highest degree.]"), 14 participants reported having such degrees ( 2 bachelor's and 12 master's) while 12 claimed to have no degrees. Yet, in Question 8 ("If you have African educational credentials in librarianship, have you ever had them evaluated by an independent agency to determine their degree of equivalence with American professional requirements?"), only 12 said that they had African credentials in librarianship and 14 stated that they did not have them. ${ }^{19}$ In this case, two respondents would simply appear to have erroneously supplied discordant answers to these questions; while unfortunate, it does not significantly change the basic picture that is derived. That is, prior to the survey, approximately 50 percent of the respondents (plus or minus four percentage points) had earned professional librarian credentials in Africa. ${ }^{20}$

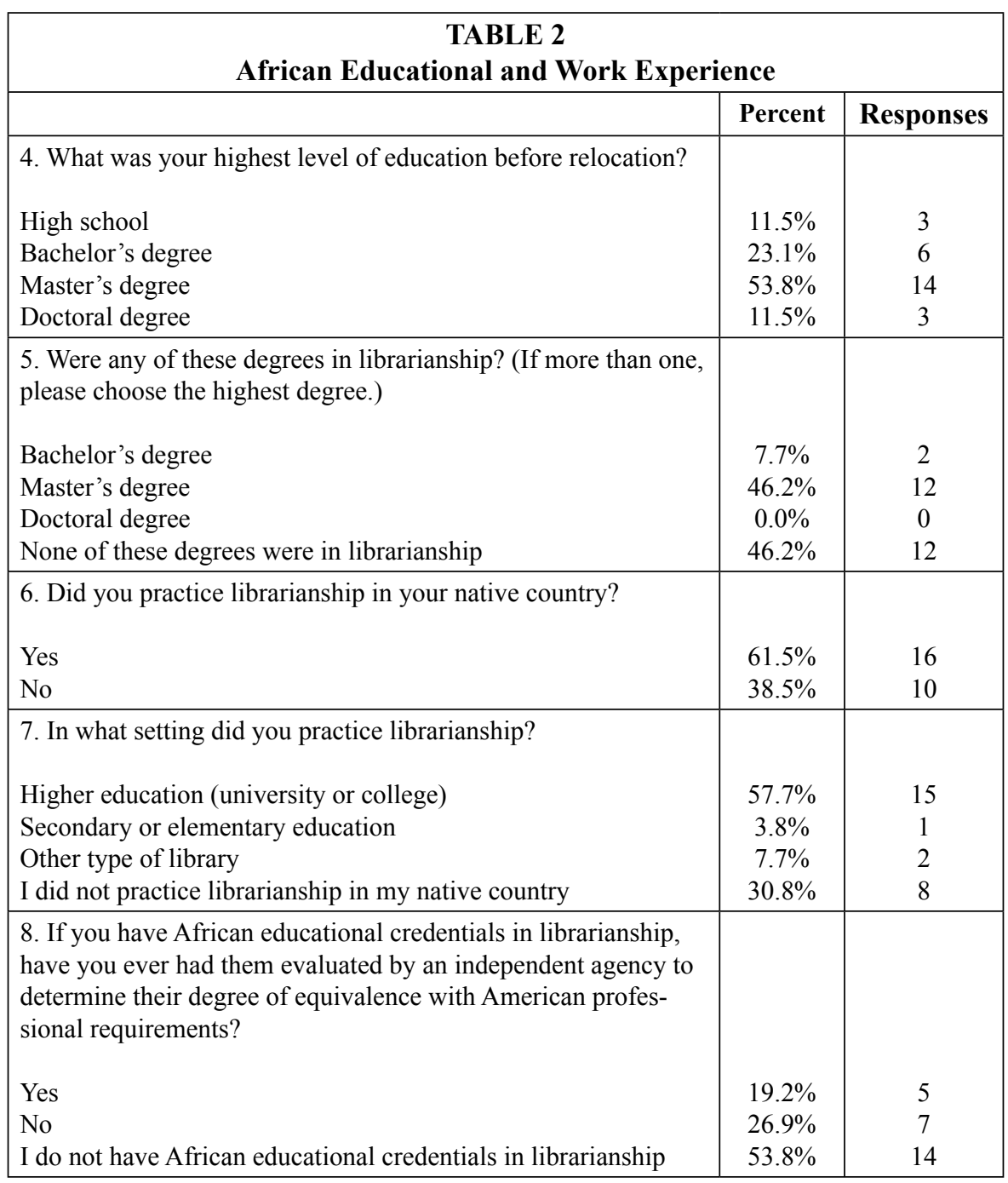




\begin{tabular}{|c|c|c|}
\hline \multicolumn{3}{|c|}{$\begin{array}{c}\text { TABLE } 3 \\
\text { American Educational and Career Search Experience }\end{array}$} \\
\hline & Percent & Responses \\
\hline $\begin{array}{l}\text { 9. Did you undertake university studies in librarianship in the } \\
\text { USA? (If so, please select the highest degree completed.) }\end{array}$ & & \\
\hline I did not undertake any university studies in librarianship in the USA & $38.5 \%$ & 10 \\
\hline Courses were taken but no degree was completed & $3.8 \%$ & 1 \\
\hline Bachelor's degree & $3.8 \%$ & 1 \\
\hline Master's degree & $53.8 \%$ & 14 \\
\hline Doctoral degree & $0.0 \%$ & 0 \\
\hline \multicolumn{3}{|l|}{$\begin{array}{l}\text { 10. After relocating to the USA, were you able to secure a position } \\
\text { as a professional librarian? }\end{array}$} \\
\hline Yes & $73.1 \%$ & 19 \\
\hline No & $26.9 \%$ & 7 \\
\hline \multicolumn{3}{|l|}{$\begin{array}{l}\text { 11. If no, which term would best describe your employment his- } \\
\text { tory in the USA? }\end{array}$} \\
\hline Paraprofessional library positions(s) & $28.6 \%$ & 2 \\
\hline Nonlibrary position(s) in an academic setting & $28.6 \%$ & 2 \\
\hline Government job(s) & $0.0 \%$ & 0 \\
\hline Private sector jobs & $42.9 \%$ & 3 \\
\hline \multicolumn{3}{|l|}{$\begin{array}{l}\text { 12. If you are not able to secure a professional librarian position in } \\
\text { the USA, is there any possibility that you will return to your native } \\
\text { country? }\end{array}$} \\
\hline Yes & $28.6 \%$ & 2 \\
\hline No & $71.4 \%$ & 5 \\
\hline
\end{tabular}

\section{American Educational and Career Search Experience}

Almost three-quarters $(73.1 \%)$ of the respondents reported that they had been able to secure positions as professional librarians in the United States, in most cases after a job search of less than one year (see table 3). Of those who were unable to find professional library employment, a minority $(28.6 \%)$ indicated that they would return to their native countries if they could not obtain a professional post, while most $(71.4 \%)$ were determined to stay, citing either more favorable economic conditions in the United States or continuing problems in their homelands as their motivation. Over half of the survey participants (53.8\%) stated that they had earned master's degrees in librarianship from American institutions.

\section{American Work Experience}

A very high percentage of survey participants $(78.9 \%)$ reported working as librarians in the United States for more than six years, with a significant number of them (42.1\%) having been employed for over ten years (see table 4). Job responsibilities were well distributed across a full range of professional duties, with reference positions being most common. In general, the respondents had not changed institutions frequently, with almost half of them $(41.2 \%)$ working at the institution where they were first hired and even more (52.6\%) having changed employers one to three times.

\section{Perceptions of American Work Experience}

A high percentage of the respondents $(70.6 \%)$ said that they enjoyed a good 


\begin{tabular}{|c|c|c|}
\hline \multicolumn{3}{|c|}{$\begin{array}{c}\text { TABLE } 4 \\
\text { American Work Experience }\end{array}$} \\
\hline & Percent & Responses \\
\hline \multicolumn{3}{|c|}{$\begin{array}{l}\text { 13. How long did you search for your first professional position } \\
\text { as a librarian in the USA? }\end{array}$} \\
\hline 1 year or less & $78.9 \%$ & 15 \\
\hline $2-5$ years & $10.5 \%$ & 2 \\
\hline 6 or more years & $10.5 \%$ & 2 \\
\hline \multicolumn{3}{|c|}{$\begin{array}{l}\text { 14. How long have you been working as a professional librarian } \\
\text { in the USA? }\end{array}$} \\
\hline 1 year or less & $0.0 \%$ & 0 \\
\hline $2-5$ years & $21.1 \%$ & 4 \\
\hline $6-9$ years & $36.8 \%$ & 7 \\
\hline 10 or more years & $42.1 \%$ & 8 \\
\hline \multicolumn{3}{|c|}{ 15. In what type of library are you working now? } \\
\hline College or university & $68.4 \%$ & 13 \\
\hline Secondary or elementary & $5.3 \%$ & 1 \\
\hline Governmental & $0.0 \%$ & 0 \\
\hline Public & $21.1 \%$ & 4 \\
\hline Special or corporate & $5.3 \%$ & 1 \\
\hline \multicolumn{3}{|c|}{ 16. Which term would best describe your current position? } \\
\hline Public Services/Reference & $47.4 \%$ & 9 \\
\hline Acquisitions & $10.5 \%$ & 2 \\
\hline Cataloging & $10.5 \%$ & 2 \\
\hline Bibliographer & $10.5 \%$ & 2 \\
\hline Systems & $0.0 \%$ & 0 \\
\hline Access Services & $5.3 \%$ & 1 \\
\hline Instruction & $10.5 \%$ & 2 \\
\hline Administration & $5.3 \%$ & 1 \\
\hline \multicolumn{3}{|c|}{$\begin{array}{l}\text { 17. Since your initial hiring, how many times have you changed } \\
\text { institutions? }\end{array}$} \\
\hline 0 & $41.2 \%$ & 8 \\
\hline $1-3$ & $52.6 \%$ & 10 \\
\hline 4 or more & $5.3 \%$ & 1 \\
\hline
\end{tabular}

working relationship with other library staff members (see table 5). Nevertheless, a significant number of participants $(41.2 \%)$ did indicate that they had encountered discrimination at some point from their library colleagues, with far fewer (23.5\%) reporting the contrary. Most of the librarians $(52.9 \%)$ responded that they had been promoted or advanced to a more responsible professional position at some point in their careers.

\section{Perceptions of Possible Barriers}

The respondents' opinions were mixed with regard to whether or not educational credentials from an American library school were necessary to be hired by American academic libraries. Almost 
half of the respondents (47\%) believed that such credentials were required, whereas one quarter $(23.5 \%)$ did not feel that they were necessary (see table 6). On the other hand, a strong majority of the survey participants $(64.7 \%)$ believed that issues regarding the acceptability of foreign academic degrees are a significant barrier for African librarians with foreign degrees seeking positions as academic librarians in the United States. Approximately half of the subjects (53\%) felt that English language skills are an obstacle for an African librarian who wishes to work as an academic librarian in the United States. Finally, the survey showed that most of the respondents $(70.6 \%)$ believed that library administrators were not well informed regarding the state of library training and education in Africa.

\section{Analysis}

Statistical analysis of the data derived from the survey focused on two issues. First, was there a statistically significant difference in the ability to find employment in American libraries between African librarians who studied librarianship in Africa and submitted their academic credentials for equivalence certification and those who did not have their degrees evaluated? Second, were there statistically significant attitudinal differences between librarians who had studied librarianship in Africa and those who had not with regard to their experiences working in American libraries?

With regard to method, it must be noted that the relatively small size of the survey invariably produced contingency tables in which 20 percent or more of the

\begin{tabular}{|l|l|l|}
\hline \multicolumn{2}{|c|}{ TABLE 5 } \\
\hline \multicolumn{2}{|c|}{ Perceptions of American Work Experience } \\
\hline $\begin{array}{l}\text { With regard to your experiences working as a librarian in the } \\
\text { USA, would you agree or disagree with the following state- } \\
\text { ments? }\end{array}$ & Percent & Responses \\
\hline 18. I have felt welcome and had a good working relationship & & \\
with other library staff members. & & \\
& & \\
Strongly agree & $23.5 \%$ & 4 \\
Agree & $47.1 \%$ & 8 \\
Neither agree nor disagree & $23.5 \%$ & 4 \\
Disagree & $5.9 \%$ & 1 \\
Strongly disagree & $0.0 \%$ & 0 \\
\hline 19. I have encountered discrimination from other library staff & & \\
members. & & \\
Strongly agree & $5.9 \%$ & 1 \\
Agree & $35.3 \%$ & 6 \\
Neither agree nor disagree & $35.3 \%$ & 6 \\
Disagree & $17.6 \%$ & 3 \\
Strongly disagree & $5.9 \%$ & 1 \\
\hline 20. I was eventually promoted or moved on to a more respon- & & \\
sible library position. & & \\
Strongly agree & $17.6 \%$ & 3 \\
Agree & $35.3 \%$ & 6 \\
Neither agree nor disagree & $41.2 \%$ & 7 \\
Disagree & $5.9 \%$ & 1 \\
Strongly disagree & $0.0 \%$ & 0 \\
\hline
\end{tabular}




\begin{tabular}{|c|c|c|}
\hline \multicolumn{3}{|l|}{$\begin{array}{c}\text { TABLE } 6 \\
\text { Perceptions of Possible Barriers }\end{array}$} \\
\hline $\begin{array}{l}\text { With regard to your experiences working as a librarian in the } \\
\text { USA, would you agree or disagree with the following statements? }\end{array}$ & Percent & Responses \\
\hline \multicolumn{3}{|l|}{$\begin{array}{l}\text { 21. In order to be hired to work in an academic library in the } \\
\text { USA, it is necessary for an African librarian to have educational } \\
\text { credentials from an American library school. }\end{array}$} \\
\hline Strongly agree & $29.4 \%$ & 5 \\
\hline Agree & $17.6 \%$ & 3 \\
\hline Neither agree nor disagree & $29.4 \%$ & 5 \\
\hline Disagree & $17.6 \%$ & 3 \\
\hline Strongly disagree & $5.9 \%$ & 1 \\
\hline \multicolumn{3}{|l|}{$\begin{array}{l}\text { 22. Library hiring managers in the USA are well-informed } \\
\text { regarding the state of library training and education in general } \\
\text { in Africa. }\end{array}$} \\
\hline Strongly agree & $0.0 \%$ & 0 \\
\hline Agree & $0.0 \%$ & 0 \\
\hline Neither agree nor disagree & $29.4 \%$ & 5 \\
\hline Disagree & $41.2 \%$ & 7 \\
\hline Strongly disagree & $29.4 \%$ & 5 \\
\hline \multicolumn{3}{|l|}{$\begin{array}{l}\text { 23. Issues regarding the acceptability of foreign academic } \\
\text { credentials are a significant barrier for an African librarian with } \\
\text { a foreign degree seeking a position as an academic librarian in } \\
\text { the USA. }\end{array}$} \\
\hline Strongly agree & $11.8 \%$ & 2 \\
\hline Agree & $52.9 \%$ & 9 \\
\hline Neither agree nor disagree & $35.3 \%$ & 6 \\
\hline Disagree & $0.0 \%$ & 0 \\
\hline Strongly disagree & $0.0 \%$ & 0 \\
\hline \multicolumn{3}{|l|}{$\begin{array}{l}\text { 24. English language skills are a significant barrier for an } \\
\text { African librarian seeking a position as an academic librarian in } \\
\text { the USA. }\end{array}$} \\
\hline Strongly agree & $11.8 \%$ & 2 \\
\hline Agree & $41.2 \%$ & 7 \\
\hline Neither agree nor disagree & $23.5 \%$ & 4 \\
\hline Disagree & $23.5 \%$ & 4 \\
\hline Strongly disagree & $0.0 \%$ & 0 \\
\hline
\end{tabular}

cells had frequencies of less than five. Consequently, it was necessary for the authors to use Fisher's Exact Probability Test rather than a chi-square test in analyzing these data. In addition, when examining the answers to the attitudinal questions, the Freeman-Halton Extension of the Fisher Exact Probability Test for two-row by three-column contingency tables was employed.

Of the twenty-six respondents who answered this question- "If you have African educational credentials in librarianship, have you ever had them evaluated by an independent agency to determine their degree of equivalence 
with American professional requirements?" - five responded affirmatively and seven negatively; fourteen said that they did not possess African credentials. Two of the five librarians who had their credentials evaluated reported that they had obtained professional positions in American libraries, while three others who had their degrees examined for equiva- lence stated that they had not been able to find professional employment. On the other hand, five of the respondents who did not have their credentials evaluated went on to get jobs as librarians and two others, who did not, said that they had not found professional work in an American library. Analysis of these groups using Fisher's Exact Test indicated that there was

\begin{tabular}{|c|c|c|c|}
\hline \multicolumn{4}{|c|}{$\begin{array}{c}\text { TABLE } 7 \\
\text { Analysis of Attitudinal Responses }\end{array}$} \\
\hline & Percent & Responses & P Value \\
\hline $\begin{array}{l}\text { In order to be hired to work in an academic library in } \\
\text { the USA, it is necessary for an African librarian to have } \\
\text { educational credentials from an American library school. } \\
\text { Respondents who studied Librarianship in Africa } \\
\text { Strongly Agree or Agree } \\
\text { Neither Agree nor Disagree } \\
\text { Disagree or Strongly Disagree } \\
\text { Respondents who did not study Librarianship in Africa } \\
\text { Strongly Agree or Agree } \\
\text { Neither Agree nor Disagree } \\
\text { Disagree or Strongly Disagree }\end{array}$ & $\begin{array}{c}12.5 \% \\
37.5 \% \\
50.0 \% \\
\\
77.7 \% \\
22.2 \% \\
0.0 \%\end{array}$ & $\begin{array}{l}1 \\
3 \\
4\end{array}$ & .01 \\
\hline $\begin{array}{l}\text { I have felt welcome and had a good working relationship } \\
\text { with other library staff members. } \\
\text { Respondents who studied Librarianship in Africa } \\
\text { Strongly Agree or Agree } \\
\text { Neither Agree nor Disagree } \\
\text { Disagree or Strongly Disagree } \\
\text { Respondents who did not study Librarianship in Africa } \\
\text { Strongly Agree or Agree } \\
\text { Neither Agree nor Disagree } \\
\text { Disagree or Strongly Disagree }\end{array}$ & $\begin{array}{c}87.5 \% \\
12.5 \% \\
0.0 \% \\
\\
55.5 \% \\
33.3 \% \\
11.1 \% \\
\end{array}$ & $\begin{array}{l}5 \\
3 \\
1 \\
\end{array}$ & .42 \\
\hline $\begin{array}{l}\text { I have encountered discrimination from other library } \\
\text { staff members. } \\
\text { Respondents who studied Librarianship in Africa } \\
\text { Strongly Agree or Agree } \\
\text { Neither Agree nor Disagree } \\
\text { Disagree or Strongly Disagree } \\
\text { Respondents who did not study Librarianship in Africa } \\
\text { Strongly Agree or Agree } \\
\text { Neither Agree nor Disagree } \\
\text { Disagree or Strongly Disagree }\end{array}$ & $\begin{array}{l}25.0 \% \\
37.5 \% \\
37.5 \% \\
\\
55.5 \% \\
33.3 \% \\
11.1 \%\end{array}$ & $\begin{array}{l}2 \\
3 \\
3\end{array}$ & .26 \\
\hline
\end{tabular}




\begin{tabular}{|c|c|c|c|}
\hline \multicolumn{4}{|c|}{$\begin{array}{c}\text { TABLE } 8 \\
\text { Continuation of Analysis of Attitudinal Responses }\end{array}$} \\
\hline & Percent & Responses & P Value \\
\hline $\begin{array}{l}\text { Library hiring managers in the USA are well-informed } \\
\text { regarding the state of library training and education in } \\
\text { general in Africa. } \\
\text { Respondents who studied Librarianship in Africa } \\
\text { Strongly Agree or Agree } \\
\text { Neither Agree nor Disagree } \\
\text { Disagree or Strongly Disagree } \\
\text { Respondents who did not study Librarianship in Africa } \\
\text { Strongly Agree or Agree } \\
\text { Neither Agree nor Disagree } \\
\text { Disagree or Strongly Disagree }\end{array}$ & $\begin{array}{c}0.0 \% \\
25.0 \% \\
75.0 \%\end{array}$ & $\begin{array}{l}0 \\
2 \\
6\end{array}$ & .99 \\
\hline $\begin{array}{l}\text { Issues regarding the acceptability of foreign academic } \\
\text { credentials are a significant barrier for an African } \\
\text { librarian with a foreign degree seeking a position as an } \\
\text { academic librarian in the USA. } \\
\text { Respondents who studied Librarianship in Africa } \\
\text { Strongly Agree or Agree } \\
\text { Neither Agree nor Disagree } \\
\text { Disagree or Strongly Disagree } \\
\text { Respondents who did not study Librarianship in Africa } \\
\text { Strongly Agree or Agree } \\
\text { Neither Agree nor Disagree } \\
\text { Disagree or Strongly Disagree }\end{array}$ & $\begin{array}{c}50.0 \% \\
50.0 \% \\
0.0 \% \\
\\
77.7 \% \\
22.2 \% \\
0.0 \% \\
\end{array}$ & $\begin{array}{l}7 \\
2 \\
0\end{array}$ & .13 \\
\hline $\begin{array}{l}\text { English language skills are a significant barrier for an } \\
\text { African librarian seeking a position as an academic } \\
\text { librarian in the USA. } \\
\text { Respondents who studied Librarianship in Africa } \\
\text { Strongly Agree or Agree } \\
\text { Neither Agree nor Disagree } \\
\text { Disagree or Strongly Disagree } \\
\text { Respondents who did not study Librarianship in Africa } \\
\text { Strongly Agree or Agree } \\
\text { Neither Agree nor Disagree } \\
\text { Disagree or Strongly Disagree }\end{array}$ & $\begin{array}{l}62.5 \% \\
25.0 \% \\
12.5 \%\end{array}$ & $\begin{array}{l}5 \\
2 \\
1\end{array}$ & .81 \\
\hline
\end{tabular}

no statistically significant difference $(p=$ .55) in the ability to find professional work in American academic libraries between African librarians who had their African credentials evaluated for equivalency with American degrees and those who did not.
To analyze the seven questions that focused on the attitudes of the respondents toward their experiences working in American libraries, the authors collapsed the five responses that were possible for each question into three groups: 
"Strongly agree" and "Agree" became one single group; "Neither agree nor disagree" formed another, and "Strongly disagree" and "Disagree" were combined to make a third class. In each case, the answers provided by respondents who had studied librarianship in Africa were separated from those who had not and then the two sets of answers were compared using Fisher's Exact Test. In only one case- "In order to be hired to work in an academic library in the USA, it is necessary for an African librarian to have educational credentials from an American library school" - was the frequency distribution between the two groups found to be statistically significant $(p=.01)$ (see table 7). Librarians who had not studied librarianship in Africa were very strongly disposed to agree with the notion that American credentials were necessary, while those who had earned credentials in Africa were almost completely opposed or neutral toward the statement. It is interesting to observe, however, that, in response to a later, related question"Issues regarding the acceptability of foreign academic credentials are a significant barrier for an African librarian with a foreign degree seeking a position as an academic librarian in the USA" - none of the librarians who had been educated in Africa disagreed with the statement and half of them agreed with it (see table 8). With regard to the other questions, the frequency distributions of the responses given by the two groups were essentially indistinguishable. ${ }^{21}$

\section{Discussion and Conclusions}

In seeking to answer the most fundamental questions regarding African librarians of the diaspora who are working in American academic libraries, the survey's results have given rise to many others, perhaps even more interesting, that should form the basis of further research. Among them would certainly be the issue of why, in a completely anonymous survey, more than half of the respondents declined to reveal their countries of ori- gin. Any subsequent studies on this point should probably incorporate a means of sensitively but conclusively identifying the reasons behind such reluctance.

The ambiguous acceptability of foreign educational credentials in American academic libraries is a very important issue that could not be clarified by this study. Unfortunately, the survey's sample of librarians with African degrees was simply too small to provide a finding that could be confidently considered to be representative of a broader population. Nevertheless, the authors strongly believe that deeper and more expansive research on this point-not only with Africans but with other racial and cultural groups as well-should definitely be carried out.

Another area for future inquiry would follow from the apparent absence of North African participants in the survey. This was a very surprising finding and one that cannot be adequately explained at the present time. Although theoretically possible, it seems highly unlikely that there was not a single North African immigrant librarian working in an American academic library at the time of the survey. If it is assumed that such librarians did exist, it may just have been that none of them received the invitation. On the other hand, if they did receive the invitation, they may not have self-identified as members of the target population or, for some other reason, they may have preferred not to participate. Finally, the possibility cannot be dismissed that there actually were North African librarians who took the survey but chose not to divulge their nationalities.

Perhaps the most significant and troubling issue raised by the survey's results was the fact that more than 40 percent of the respondents reported that they had encountered workplace discrimination in the library setting. What was the nature of the discrimination? How did it manifest itself and what did the subjects do to cope with it? Was there any institutional support available and what was the ultimate impact of the discrimination on the 
individuals' careers? Obviously, these are all vexing questions that warrant further research.

Moving beyond the scope of the present study, we believe that additional inquiry should be focused on the satisfaction that African librarians may or may not have found working in American libraries; the job mobility that they have experienced within and between institutions and how their career aspirations are, or are not, being fulfilled. Finally, there is the question of this group's views regarding their own role in the diaspora and the degree to which they wish to and believe that they can serve as change agents for libraries and librarianship in their countries of origination.

The relationship between these expatriate librarians and their ancestral lands is of particular significance, since the survey's results clearly suggest that African librarians working in American academic libraries have generally been professionally successful. It also appears that they are well established within their institutions and possess a diverse collective skill set comprising practical experience in administration, technical services, public services, and instruction. Consequently, as a group and as individuals, they represent a substantial untapped resource for the African continent.

During the past ten years, many international commissions and African nations have devoted a great deal of effort toward establishing links with the diaspora. Some of these initiatives have sought to foster "temporary returns" in which trained professionals would return to their countries of origin for short periods of time to share their skills. Others have encouraged "virtual returns" by which émigrés would transfer their knowledge back to their homelands through electronic telecommunications. ${ }^{22}$ Unfortunately, to date, none of these programs have been focused on librarianship and, furthermore, the International Organization for Migration has recently made this observation: "While a growing number of governments increasingly acknowledge the importance of diaspora engagement, many still lack the capacity to design effective diaspora policies and to implement them on a meaningful scale. ${ }^{23}$ Certainly this would appear to be an area in which involvement by an entity such as the Carnegie Corporation of New York or the Mortenson Center for International Library Programs could have a significant catalytic influence.

It is for these reasons that the authors believe the first step toward reconnecting African librarians of the diaspora with the universities and libraries of their native lands should be taken by these librarians themselves. A good start might be the establishment of a collective identity either through a new professional organization that would begin by building a database of members or, alternatively, the creation of a simple Facebook page that could be used for informal networking and would form the foundation for a more formally defined group. Once the true number of expatriate African librarians is finally known and a medium for establishing communication to and among them is developed, entirely new opportunities for action will become possible including outreach by African institutions to individual librarians as well as groups of librarians reaching back to offer their expertise on an individual, national, regional and even pan-African basis. 


\section{Appendix: Survey Instrument}

The purpose of this research study will be to assess the perceptions of African librarians who are residents of the United States of America and are working as or searching for employment as academic librarians. There are no foreseeable risks associated with this project nor will there be any direct benefit to you. This is an entirely anonymous questionnaire that will take approximately five to seven minutes to complete. Your responses will not be identifiable in any way. All responses are confidential and will be kept in a secure manner. Your participation is voluntary and you may withdraw from the project at any time. This study is being conducted by Abiodun Ibraheem and Christopher Devine of the Robert Morris University Library. If you have any questions, Abiodun may be contacted at ibraheem@rmu.edu or 412-397-3258 and Christopher can be reached at devinec@rmu.edu or 412-397-4358. You may also contact Robert Morris University's Human Subject Protection Advocate in the Institutional Research Board office at 412-397-6227 if you have any additional questions or concerns.

1. Are you an African librarian who is working as or searching for employment as an academic librarian in the USA? (For the purposes of this survey, the term "African librarian" will refer to a person born in Africa, who emigrated after the age of eighteen and currently resides in the USA and who possesses educational credentials that qualify him or her to work professionally as a librarian in the US and/or Africa.)

- Yes

- No

2. (OPTIONAL) What is your country of origin?

3. Why did you relocate to the USA? (If more than one reason, please choose the one that you would consider to be most important.)

- Received political asylum

- Refugee from war and/or insecurity in my homeland

- Educational reasons

- Economic opportunity

- Marriage or reunification with family

- If other, please specify

4. What was your highest level of education before relocation?

- High school

- Bachelor's degree

- Master's degree

- Doctoral degree

- Other (please specify)

5. Were any of these degrees in librarianship? (If more than one, please choose the highest degree.)

- Bachelor's degree

- Master's degree

- Doctoral degree

- None of these degrees were in librarianship

6. Did you practice librarianship in your native country?

- Yes

- No 
7. In what setting did you practice librarianship?

- Higher education (university or college)

- Secondary or elementary education

- Other type of library

- I did not practice librarianship in my native country

8. If you have African educational credentials in librarianship, have you ever had them evaluated by an independent agency to determine their degree of equivalence with American professional requirements?

- Yes

- No

- I do not have African educational credentials in librarianship

9. Did you undertake university studies in librarianship in the USA? (If so, please select the highest degree completed.)

- I did not undertake any studies in librarianship in the USA

- Courses were taken but no degree was completed

- Bachelor's degree

- Master's degree

- Doctoral degree

10. After relocating to the USA, were you able to secure a position as a professional librarian?

- Yes

- No

11. If no, which term would best describe your employment history in the USA?

- Paraprofessional library position(s)

- Nonlibrary position(s) in an educational setting

- Government job(s)

- Private sector job(s)

- If other, please specify

12. If you are not able to secure a professional librarian position in the USA, is there any possibility that you will return to your native country?

- Yes

- No

13. If not, why will you stay?

14. How long have you been working as a professional librarian in the USA?

1 year or less

- 2-5 years

- 6-9 years

- 10 or more years

15. How long did you search for your first professional position as a librarian in the USA?

- 1 year or less

- 2-5 years

- More than 6 years 
16. In what type of library are you working now?

- College or university

- Secondary or elementary

- Governmental

- Public

- Special or corporate

17. Which term would best describe your current position?

- Public Services/Reference

- Acquisitions

- Cataloging

- Bibliographer

- Systems

- Access Services

- Instruction

- Administration

- If other, please specify

18. Since your initial hiring, how many times have you changed institutions?

- 0

- $1-3$

- 4 or more

With regard to your experiences working as a librarian in the USA, would you agree or disagree with the following statements:

19. In order to be hired to work in an academic library in the USA, it is necessary for an African librarian to have educational credentials from an American library school.

- Strongly agree

- Agree

- Neither agree nor disagree

- Disagree

- Strongly disagree

20. I have felt welcome and had a good working relationship with other library staff members.

- Strongly agree

- Agree

- Neither agree nor disagree

- Disagree

- Strongly disagree

21. I have encountered discrimination from other library staff members.

- Strongly agree

- Agree

- Neither agree nor disagree

- Disagree

- Strongly disagree 
22. I was eventually promoted or moved on to a more responsible library position. Strongly agree

- Agree

- Neither agree nor disagree

- Disagree

- Strongly disagree

23. Library hiring managers in the USA are well-informed regarding the state of library training and education in general in Africa.

- Strongly agree

- Agree

- Neither agree nor disagree

- Disagree

- Strongly disagree

24. Issues regarding the acceptability of foreign academic credentials are a significant barrier for an African librarian with a foreign degree seeking a position as an academic librarian in the USA.

- $\quad$ Strongly agree

- Agree

- Neither agree nor disagree

- Disagree

- Strongly disagree

25. English language skills are a significant barrier for an African librarian seeking a position as an academic librarian in the USA.

- Strongly agree

- Agree

- Neither agree nor disagree

- Disagree

- $\quad$ Strongly disagree

\section{Notes}

1. United Nations Expert Group Meeting on Measuring International Migration, International Migration Statistics in the ECA Region, prepared by Omar Sarr (New York: United Nations, Dec. 4-7, 2006), 3-4, available online at http://unstats.un.org/unsd/demographic/meetings/egm/ migrationegm06/DOC\%2023\%20ECA.pdf [accessed 20 May 2011].

2. The Oxford English Dictionary 2nd ed., s.v. "Diaspora."

3. Robin Cohen has, however, persuasively argued that concept of "diaspora" can be appropriately extended to include the migrations of a number of other peoples, among which would be the Chinese, Lebanese, Irish, Sikhs, and Palestinians. Robin Cohen, Global Diasporas: An Introduction (Seattle: University of Washington Press, 1997), 180-86.

4. See: Michael L. Conniff and Thomas J. Davis, Africans in the Americas: A History of the Black Diaspora (New York: St. Martin's Press, 1994); Ronald Segal, The Black Diaspora (New York: Farrar, Straus and Giroux, 1995); Patrick Manning, The African Diaspora: A History through Culture (New York: Columbia University Press, 2009); Michael A. Gomez, Reversing Sail: A History of the African Diaspora (Cambridge, U.K.: Cambridge University Press, 2005).

5. C.M. Rogerson and J.M. Rogerson, "Dealing in Scarce Skills: Employer Responses to the Brain Drain in South Africa," in Destinations Unknown: Perspectives on the Brain Drain in Southern Africa, eds. David A. McDonald and Jonathan Crush (Pretoria: Africa Institute of South Africa, 2002), 75.

6. Reginald Herbold Green, "A Cloth Untrue: The Evolution of Structural Adjustment in Sub-Saharan Africa," Journal of International Affairs 52, no. 1 (1998): 207-32.

7. Yann Lebeau and David Mills, “From 'Crisis' to 'Transformation'? Shifting Orthodoxies 
of African Higher Education Policy and Research," Learning and Teaching 1, no. 1 (2008): 66-67.

8. Adonis Hoffman, "The Destruction of Higher Education in Sub-Saharan Africa," The Journal of Blacks in Higher Education 10 (1995/1996): 85.

9. World Bank, "Retaining Teaching Capacity in African Universities: Problems and Prospects," Findings: Africa Region 39 (1995): 1. For recent efforts to stem the immigration of academics toward Europe, see: European University Association, Africa-Europe Higher Education Cooperation for Development: Meeting Regional and Global Challenges (Brussels: European University Association, 2010).

10. The libraries surveyed were in Botswana, Ethiopia, Ghana, Kenya, Ivory Coast, Mozambique, Senegal, Sierra Leone, Sudan, Tanzania, and Zimbabwe. Diana Rosenberg, University Libraries in Africa: A Review of Their Current State and Future Potential, vol. 1, Summary (London: International African Institute, 1997), 34.

11. Carnegie Corporation of New York, Revitalizing Africa Libraries: The Challenge of a Quiet Crisis (New York: Carnegie Corporation of New York, 2000), 5.

12. Matseliso M. Moshoeshoe-Chadzingwa, "Human Resource Management in Southern African Libraries," Library Management 31, no. 6 (2010): 463.

13. Patrick Ngulube, "Staff Retention in the National Archives of Zimbabwe," African Journal of Library, Archives \& Information Science 10, no. 2 (2000): 142. See also: Julita Nawe, "Strategizing Financing of Public University Libraries in East Africa," Library Management 25, no. 8/9 (2004): 382.

14. American Library Association, ALA Policy Manual: Section Two: Positions and Public Policy Statements (2011), 32, available online at www.ala.org/ala/aboutala/governance/policymanual/ updatedpolicymanual/section2.pdf [accessed 20 May 2011].

15. Michael Dowling, "International Credentialing, Certification, and Recognition in the United States," New Library World 108, no. 1/2 (2007): 80.

16. Amber T. Burtis, Melissa A. Hubbard, and Megan C. Lotts, "Foreign LIS Degrees in Contemporary US Academic Libraries," New Library World 111, no. 9/10 (2010): 408.

17. The listservs targeted by the survey were: ACQNET (www.acqweb.org/acqnet.html); ANSS-L (http://lists.ala.org/wws/info/anss-1);AUTOACQ-L (www.lsoft.com/scripts/wl.exe?SL1=AUTOACQL\&H=LISTSERV.ND.EDU); AUTOCAT(www.cwu.edu/ dcc/Autocat-ToC-2007.html); BUSLIB-L (www.willamette.edu/ gklein/buslib.htm); COLLDV-L (http://serials.infomotions.com/colldv-l/); Collib-1 (http://lists.ala.org/wws/subscribe/collib-l); Dig_Ref (http://finance.groups.yahoo.com/ group/dig_ref/); ERIL-L (http://listserv.binghamton.edu/archives/eril-1.html); GOVDOC-L ( http:// govdoc-l.org/) ; ILI-L (www.ala.org/ala/mgrps/divs/acrl/about/sections/is/ilil.cfm); LES-L (www.ala. org/ala/mgrps/divs/acrl/about/sections/les/leslistserv.cfm); Libsup-l (http://mailman2.u.washington. edu/mailman/listinfo/libsup-l) LIS-LINK (https://www.jiscmail.ac.uk/cgi-bin/webadmin?A0=lislink); LIS-Scitec (https://www.jiscmail.ac.uk/cgi-bin/webadmin?SUBED1=LIS-SCITECH\&A=1); livereference (http://groups.yahoo.com/group/livereference/); LIBREF-L (https://listserv.kent.edu/ cgi-bin/wa.exe?SUBED1=LIBREF-L\&A=1); NEWLIB-L (http://walternelson.com/dr/newlib-l); PDA Libraries (http://librarysupportstaff.com/4subscribe.html) ; PUBLIB (http://lists.webjunction.org/ publib/); SERIALST (www.uvm.edu/ bmaclenn/serialst.html); STS-L (http://lists.ala.org/wws/info/ sts-l); Web4Lib (http://lists.webjunction.org/web4lib/)

18. Aaron Terrazas, "African Immigrants in the United States," Migration Information Source, Feb. 2009, available online at www.migrationinformation.org/usfocus/display.cfm?ID=719 [accessed 14 November 2011). For the history of libraries and librarianship in Egypt, see: Encyclopedia of Library and Information Science, s.v."Libraries in Egypt." For a good summary of more recent developments in Egyptian libraries, see: Shawky Salem, "The Drive towards a National Information Infrastructure in Egypt: an Overview," Journal of Information Science 26 (2000): 71-74.

19. A differential of two was also found between the responses to Question 6, in which 16 participants said that they had practiced librarianship in their native countries, and Question 7, in which 18 stated that they had done the same.

20. It can be assumed, regarding the answers to Questions 6 and 7, that approximately two-thirds of the respondents (that is, between $61 \%$ and $69 \%$ ) practiced librarianship in Africa prior to emigrating.

21. For the sake of spatial economy, the responses to the question - "I was eventually promoted or moved on to a more responsible library position" - have not been included in these charts. Of the eight participants who had African credentials, three agreed with that statement, four were neutral, and one disagreed. In contrast, six of the respondents who did not have African degrees agreed with the question, three were neutral, and none disagreed. The variance in frequency distribution between the two sets was not found to be statistically significant $(p=.45)$

22. International Organization for Migration, International Dialog on Migration No. 15: Enhancing the Role of Return Migration in Fostering Development (Geneva: International Organization for Migration, 2010), 34-35.

23. International Organization for Migration, World Migration Report 2010 (Geneva: International Organization for Migration, 2010), 51. 